with invertebrates, the first of which described the relation of electrolytes to the cardiac rhythm of Jasus and Octopus, the others the respiratory exchange of certain arthropods (a crab and a scorpion) and of a marine worm (Bispira). This work was accompanied by determinations which were made by Sand of the hydrogen-ion concentration and oxygen-content of samples of sea water, in connexion with studies undertaken by colleagues. His next work concerned chamæleons. After a peculiarly neat and illuminating paper describing adequately, for the first time, the mechanism of the projection of the chamæleon's tongue (1933), he published another important paper describing the bionomics and physiology of the pigmentary activity of this animal. These papers were followed by a contribution to Biological Reviews on the comparative physiology of colour-resporse in reptiles and fishes.

After Sand's return from Cape Town to England he was appointed physiologist to the Marine Biological Laboratory at Plymouth, and thenceforward his interests were devoted to experiments on fishes, dealing primarily with certain of their sense organs. He published in 1936, in collaboration with James Gray, papers on the locomotory rhythm and spinal reflexes of the dogfish. After a preparatory period, during which he mastered the complex and delicate apparatus required, Sand attained the height of his ability and began his final work on the sense organs. This work, carried out partly in collaboration with Otto Löwenstein, involved a series of precise and beautiful experiments, and resulted in a most marked and definite advance in our knowledge not only of the labyrinth of fishes, but also of the lateral sense organs and of the peculiar ampullæ of Lorenzini. It is this last body of work for which Sand will be longest remembered, and which entitles him to rank high among British comparative physiologists. He was elected to the Royal Society in 1944. Two of his collaborators, Gray and Löwenstein, have already been mentioned; but during his whole career Sand also published joint papers with Lancelot Hogben, Enid Charles and others.

One of Sand's outstanding characteristics, the precision of his use of experimental apparatus, came out not only in his research work but also in his teaching. During his years at Cape Town he conducted a class in comparative physiology which was distinguished by its finished and flawless demonstrations. Sand served in the Royal Navy during the Second World War, and died on July 11, 1945. His death has come as a great shock to his many friends.

\section{T. A. Stephenson.}

\section{Prof. Ludwik Wertenstein}

THE tragic death of Prof. Ludwik Wertenstein, who was killed in January during the battle for Budapest, deprives Poland of one of its leading men of science, and represents a grievous loss to physicists generally, among whom he had many personal friends.

Born in Warsaw in 1885 , Wertenstein received his early education there and entered the University, which he had, however, to leave in 1906, after one year of study, because of taking part in the students' protest strike against the policy of the Tzarist regime. $\mathrm{He}$ went to Paris, where he entered the Sorbonne and began to work in Madame Curie's laboratory. His first scientific work was published in 1909 and was soon followed by a series of papers dealing mainly with the properties of recoil atoms of radioactive elements, a subject which, with his usual thoroughness, he pursued and studied for many years. He measured the range, ionization and charge of recoil atoms, and some conclusions of these experiments were recently confirmed in the study of the ionizing properties of fission fragments.

In 1913, the Scientific Society of Warsaw founded, under the auspices of Madame Curie, the Radiological Laboratory, where research work on radioactivity was to be centred. Madame Curie sent her two most outstanding pupils, Danysz and Wertenstein, to Warsaw to direct the work there. After the death of Danysz in 1914, Wertenstein became director of the Laboratory, and he remained there until its destruction in 1939. In 1919 he was appointed to the chair of radioactivity at the Free University of Poland, where he later founded the Laboratory of Atomic Physics. Except for the period 1925-26, which he spent at the Cavendish Laboratory under the late Lord Rutherford, all his scientific work was done in these two laboratories. Despite the constant difficulties and limitations due to lack of funds, he managed to create a centre of research which gained a high reputation abroad, and to form a school from which came a number of young men of science of standing.

Most of Wertenstein's scientific work was in the field of radioactivity; he made a detailed study of the properties of radon, found new methods for its purification, investigated its condensation properties, measured its vapour pressure and ionization potential, and determined the volume of one curie, an important quantity in radioactivity. But his interests embraced. many other branches of physies, and among the large number of papers he published are some on such divergent subjects as vacuum technique, photochemical law and isotope separation. In recent years, he concentrated mainly on nuclear physics, in particular on problems of inelastic scattering of neutrons, photonuclear effects and fission. His last paper, on gaseous fission products, published in Nature of December 29 , 1939, was sent out of Poland when it was already occupied by the Germans.

Apart from pure scientific work, Wertenstein took an active part in the organization and popularization of science in Poland. He was a member of the Academy of Technical Sciences, and president of the Physical Society of Warsaw. His agile, penetrating and critical mind, swift reasoning, and almost uncanny facility for operating with figures mentally, made every discussion in the Physical Society a lively and exciting event. His was a most remarkable and versatile mind; apart from being a brilliant experimenter and highly skilled in various techniques, he was an excellent theoretician and had a deep knowledge of mathernatics. He spoke fluently many languages, was a classical scholar and had great literary talent. His quickness and wit, combined with a deep sense of humour, made him most popular at all scientific and social gatherings. An excellent speaker, he had a particular gift of presenting difficult problems in a simple manner, and his public lectures -masterpieces in language and composition-always attracted large audiences. His articles in various magazines and Sunday papers contributed a great deal to the popularization of science in Poland. He translated a number of books into Polish, the last being Madame Curie's "Radioactivite"; the translation of this was just finished when war broke out, 
and it achieved the unique honour of being published by the underground movement; it was the main scientific book used by the students of Poland's Underground University, in which Prof. Wertenstein took an active part. Little is yet known about his fate during the war years; but he was hunted by the Germans and had to hide in various parts of the country. Finally he managed to escape to Hungary, and there, on the eve of the liberation of Budapest by the Red Army, he was killed by a shell fragment during the battle for that city.

I cannot end this note without a tribute to Prof. Wertenstein's character and personality. He possessed such virtues as made him an outstanding man even without his scientific achievements. He was exceptionally kind, generous, friendly and utterly unselfish. Everyone who knew him was charmed and attracted by his cordiality, cheerfulness and modesty. But we, his students, who worked with him closely, could most fully appreciate the integrity of his character. $\mathrm{He}$ was not merely a teacher but also a friend and counsellor; he cared not only for our intellectual needs but also for our general welfare, and would not spare any efforts to meet any of our difficulties. $\mathrm{He}$ will always remain in our memory a symbol of the ideal man of science, a perfect blend of brilliance and kindness, erudition and good humour, enthusiasm for Nature and love of humanity.

\section{J. Rotblat.}

\section{Prof. Walter Makower, O.B.E.}

The death of Prof. W. Makower at the age of sixtyfive occurred on July 7. Makower graduated from University College, London, where he took honours in chemistry ; but going to Cambridge as a research student under Thomson effected his transformation into a physicist, and his M.A. was for a thesis on the diffusion properties of radium emanation (radon). From the Cavendish Laboratory he went to Manchester as a John Harling Research Fellow under the directorship of Schuster. On the latter's retirement in 1906, Makower became lecturer on the staff of Rutherford, whose arrival in Manchester gave a great impetus to radioactive studies. Over a period of years Makower did experimental work in this subject; he showed that radium $A, B$ and $C$ all had different temperatures of volatilization and that the behaviour of the active deposit depended largely on the pressure conditions within the vessel. Later on he collaborated with Prof. S. Russ on radioactive recoil, with Fajans on the beta-rays from radium $B$ and with Moseley on the gamma radiation from the same substance; with Geiger he wrote a timely book on radioactive measurements. He had previously written one of the earliest books on radioactivity entitled "The Radioactive Substances".

Outside the precincts of the Physics Department, Makower spent a good deal of his leisure at the kiteflying station installed high up on the moors above Glossop in Derbyshire. He escaped injury when the kite he was flying was struck, setting on fire the hut in which the winding machinery was installed.

The War of 1914-18 found him serving first as a lieutenant R.N.V.R. and then as a captain R.F.C.; both positions he filled in a scientific capaoity.

After sixteen years service in the Physics Department at Manchester, Makower became attached to the research laboratory of the Dunlop Rubber Company, but he was glad to return to professional life when appointed in 1925 to the post of professor of science at the Royal Military Academy, Woolwich. This post he held until 1938 when he resigned; he was awarded the O.B.E. in 1934.

During the years of retirement he did valuable work for the Institute of Physics.

Walter Makower came of a cultured family, all the members being musical; he was no mean performer on the 'cello. Those who knew him intimately valued him most for his sense of humour and his integrity of mind. He married Dorothy Lois Drey who, with their two daughters and a son, survives him.

\section{Miss E. R. Saunders}

The obituaries of Miss E. R. Saunders in Nature of August 18, 1945, while describing her morphological and educational work, do not refer to her contributions to genetics. These were, however, of the first importance. In 1897 she began experimental plant breeding at Cambridge in collaboration with Bateson, and the results were presented to the Evolution Committee of the Royal Society in 1901. Meanwhile Mendel's work had been rediscovered in 1900. By 1901 she had established the existence of Mendelian inheritance in Lychnis, Datura and Matthiola. It is clear that she and Bateson had independently rediscovered some at least of Mendel's laws before his work was known to them. She must in fact be regarded as the 'mother' of British plant genetics.

Her later genetical research was mainly on Matthiola incana. Here she successfully analysed what was then the most complicated known case of genic interaction. Any of four independent recessive genes may render a plant of this normally hoary species glabrous. Two of them also make it white. She also described, in connexion with doubleness, what, in modern terminology, is the first case of balanced lethals, and the second case of linkage. Up to her death she continued to display a lively interest in all branches of genetics, and was treasurer of the Genetical Society. To all geneticists her death was a loss ; to many a personal loss. J. B. S. HaLdane.

\section{Dr. G. V. Buchanan}

Dr. Gwrnneth Vaughan Buchanan, senior lecturer in zoology at the University of Melbourne, died towards the end of June 1945. Dr. Buchanan was born in Sydney in November 1886, and was educated at Toorak College and the University of Melbourne. For a time she acted as professor of zoology in the University of Western Australia before she returned to her old university as senior lecturer under Sir Baldwin Spencer. To English zoologists she is perhaps best known for her outstanding work on the development of the marsupials, undertaken in conjunction with Dr. Elizabeth Frazer at University College, London, in 1918. In Australia, the great influence for good that she exercised on the many students to whom she was so much more than a mere university teacher will long be remembered. It was largely owing to her influence and enthusiasm that the McCoy Society for Field Investigation and Research came into being and became such an outstanding success. After some months of ill-health, bravely borne, she retired from active teaching in February of this year, but until the last she continued her enormous correspondence with old students scattered, by the War, to distant parts of the world.

F. WOOD JoNEs. 